\title{
Lumbar Disc Herniation in a Patient With Congenital Vertebral Body Anomaly: A Case Report
}

\author{
Cem Atabey ${ }^{1}$, Ahmet Eroğlư $^{2}$, Ali Kivanc Topuz ${ }^{3}$, Murat Velioğlư ${ }^{4}$ Mehmet Nusret Demircan ${ }^{1}$ \\ ${ }^{I}$ Department of Neurosurgery, GATA Haydarpasa Training Hospital, Istanbul, ${ }^{2}$ Department of Neurosurgery, Van Military \\ Hospital, Van, ${ }^{3}$ Department of Neurosurgery, Kasımpaşa Military Hospital, Istanbul, ${ }^{4}$ Department of Radiology, GATA \\ Haydarpasa Training Hospital, Istanbul, Turkey
}

Lumbar disc herniation is characterized with low back and leg pain resulting from the degenerated lumbar disc compressing the spinal nerve root. The etiology of degenerative spine is related to age, smoking, microtrauma, obesity, disorders of familial collagen structure, occupational and sports-related physical activity. However, disc herniations induced by congenital lumbar vertebral anomalies are rarely seen. Vertebral fusion defect is one of the causes of congenital anomalies. The pathogenesis of embryological corpus vertebral fusion anomaly is not fully known. In this paper, a 30- year-old patient who had the complaints of low back and right leg pain after falling from a height is presented. She had right L5-S1 disc herniation that had developed on the basis of S1 vertebra corpus fusion anomaly in Lumbar computed tomography. This case has been discussed in the light of literature based on evaluations of Lumbar Computed Tomography (CT) and Magnetic Resonance Imaging (MRI). This case is unique in that it is the first case with development of lumbar disc herniation associated with S1 vertebral corpus fusion anomaly. Congenital malformations with unusual clinical presentation after trauma should be evaluated through advanced radiological imaging techniques.

Key Words: Fusion anomaly $•$ Disc hernia $\cdot$ Trauma $\cdot$ Nervous system

\section{INTRODUCTION}

Walter Dandy was the first research to describe radicular pain as an extradural mass associated syndrome in $1929^{3)}$. Mixter and Barr, however, reported in 1934 that extruded disc materials cause sciatic pain and described the surgical approach $^{11)}$.

Intervertebral disc degeneration $^{18)}$, smoking, occupational and sports-related physical activity, microtrauma, such as obesity, environmental factors covered by the different forms of life ${ }^{12)}$, genetic factors ${ }^{1)}$, congenital defects of vertebral formation $^{16)}$ are involved in the etiology of lumbar disc herniation. The disc herniation depending on vertebral corpus developmental anomaly is available only one case in English Literature. Our case is the second in such nature.

\footnotetext{
- Received: July 2, 2014 • Revised: August 2, 2014

- Accepted: August 11, 2014

Corresponding Author: Ahmet Eroğlu, MD

Department of Neurosurgery, Van Military Hospital, Clinic of Neurosurgery, Van, Turkey

Tel: +90-506-203-6231, Fax: +90-432-222-0244

E-mail: drahmeteroglu@gmail.com

(2This is an Open Access article distributed under the terms of the Creative Commons Aftribution Non-Commercial License (http://creativecommons.org/ licenses/by-nc/3.0/) which permits unrestricted non-commercial use, distribution, and reproduction in any medium, provided the original work is properly cited.
}

\section{CASE REPORT}

A thirty-year-old female patient was admitted to our clinic with complaints of low back and right leg pain after a fall 3 weeks ago. Physical examination was evaluated as normal and there were not any features identified in family history. The neurological examination was described as right straight leg raising test positive at 45 degrees, full muscle strength, norm active tendon reflexes, right $\mathrm{S} 1$ dermatome hypoesthesia. Lumbar computed tomography (CT) was planned because S1 lumbar vertebra fracture was suspected in the lumbosacral graph $\mathrm{AP} / \mathrm{L}$ (Fig. 1) based on history of trauma. Lumbar magnetic resonance imaging (MRI) was performed as fusion anomaly

Fig. 1. In magnified view of AP lumbosacral graphy, there was a right paramedian bone defect in S1 vertebrae.

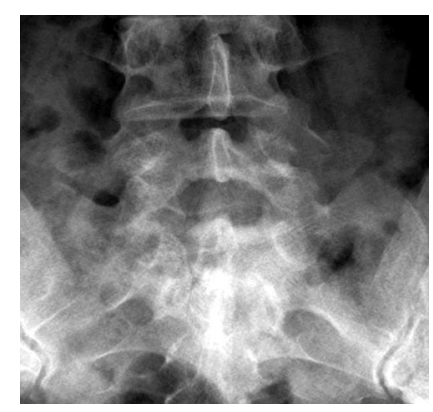


was detected but $\mathrm{S} 1$ vertebral corpus was not broken on the lumbar CT (Fig. 2). L5-S1 right paramedian disc herniation was detected with the precipitation of trauma on the lumbar MRI (Fig. 3, 4). Development of the spinal canal due to congenital defects in the lumbar MR imaging was normal (Fig. 5). The patient did not consent to surgical treatment and was referred to Physical Therapy clinic for conservative treatment. The patient's complaints decreased with physical therapy after 3 weeks.

\section{DISCUSSION}

Disc herniation occurs as a result of displacement of lumbar intervertebral disc annulus fibrosis and nucleus polyposis fibrosis in the vertebral canal ${ }^{7}$. Lumbar disc herniation can be symptomatic as a result of compression on the spinal nerves or roots. Radicular symptoms occur due to generation of nerve root ischemia because of the direct mechanical effect of the herniated disc material, or with an inflammatory response and the effect of secondary edema and compression of vascular structures".

In the etiology of the disease, cumulative microtrauma was held responsible and it is reported to be more frequently
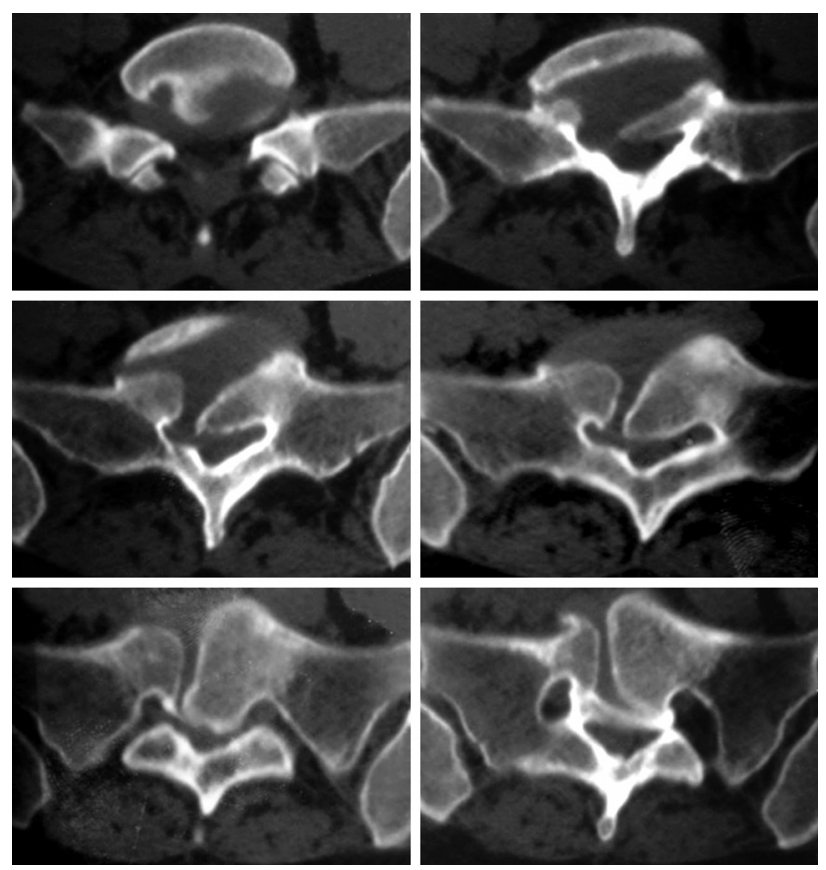

Fig. 2. Lumbar computed tomography axial images show the fusion anomaly of S1 vertebrae corpus with sclerotic margins. The gap between non-fused corpus was filled with soft tissue which has the same density as that of intervertebral disc.
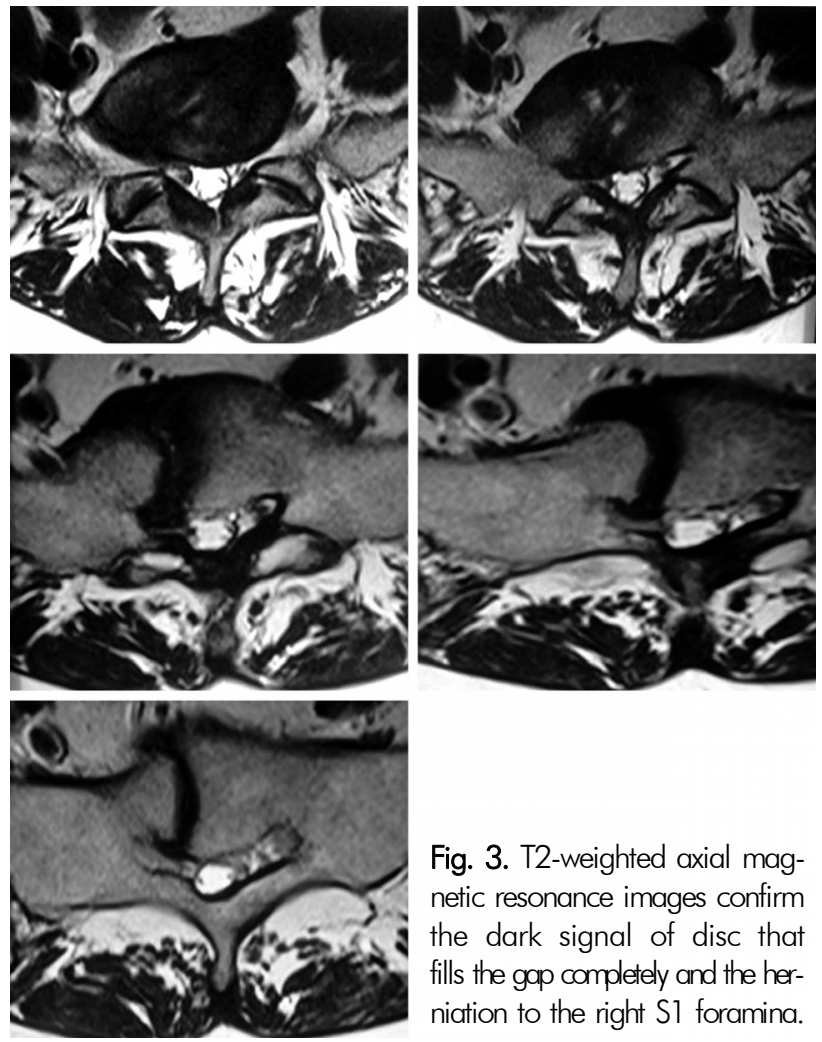

Fig. 3. T2-weighted axial magnetic resonance images confirm the dark signal of disc that fills the gap completely and the herniation to the right S1 foramina.

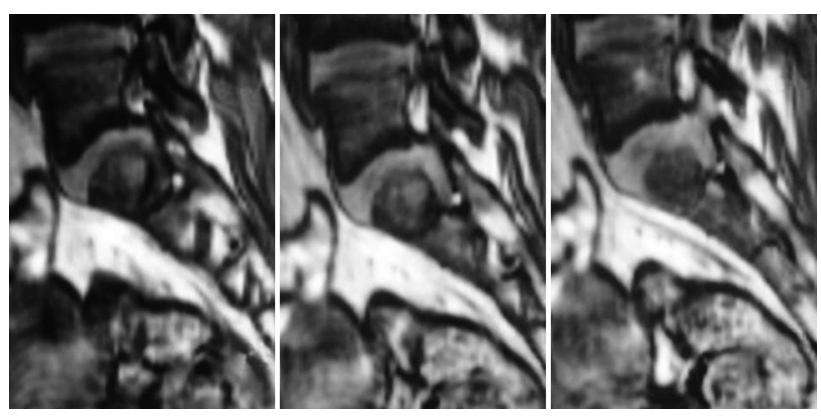

Fig. 4. Sagittal reformatted images of 3D turbo-flash sequence show the herniated disc.
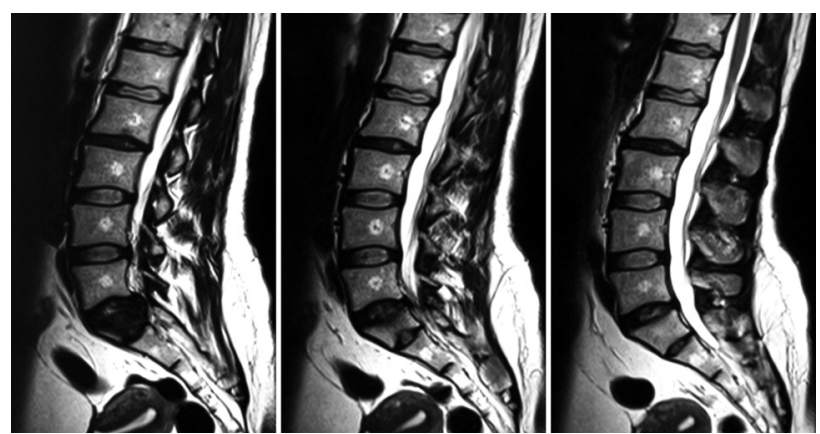

Fig. 5. T2-weighted sagittal magnetic resonance images. There was not a congenital defect of development of the spinal canal. 
encountered in those driving motor vehicles, those with sedentary life style and in smokers ${ }^{12)}$. Disc herniation triggered by congenital lumbar vertebra anomaly is a rare occasion ${ }^{16}$.

Congenital vertebrae corpus defects are rare anomalies. These anomalies are classified as disorders of formation, segmentation disorders and the composition of the two complex disorders ${ }^{5}$. Although the pathophysiology of spina bifida can be described, the embryological pathogenesis of vertebral corpus fusion anomaly is not fully known.

Mesoderm structure emerges after the second week of embryological development of the vertebrae that make up the spine. Skeletal system develops from the para-axial mesoderm and the lateral plates (somatic layer), and crista neuralis. Paraaxial mesoderm creates a series of segmented tissue block known as the somite towards caudal from both sides of the neural tube, somatomeres and occipital region. Somite differentiates in ventromedial termed as sclerotome and dorsolateral part termed dermomyotome ${ }^{10)}$.

The position of the sclerotome cells changes to surround the notochord and the spinal column in the fourth week of development. This positional change occurs with the differentiation of surrounding structures and not the active migration of those sclerotome cells ${ }^{13)}$. Thus, the resulting mesenchymal column retains segmental traces by leaving less-dense areas containing intersegmental arteries of sclerotomies blocks. The caudal part of each sclerotome segment is heavily divided and collected in the ongoing stages of development. This division is so intense that it moves towards the environment intersegmental tissue and thus, a caudal part of the sclerotome is connected to cephalic part of another sclerotome. Thus, vertebral body becomes intersegmental with the connection of intersegmental tissue and the pre-cartilaginous vertebra body ${ }^{10)}$. Among sclerotomes that are poor in cell count in cranial and rich in cell count in caudal forms, the one that contains the poo $\mathrm{r}$ area forms the intervertebral disc, while the one that contains the rich area constitutes a section of vertebral body ${ }^{10)}$. These formation defects occurring in the embryological period cause anomalies regarding the vertebra and the disc ${ }^{10)}$. Among congenital vertebral anomalies, double facet joint formation ${ }^{8)}$, the absence of pedicle ${ }^{17}$, and absence of lumbar articular processes are reported; however, vertebral corpus fusion defect as in our case was reported before only one time ${ }^{2)}$. Cho and friends described vertebra fusion anomaly as the butterfly vertebra $^{2}$. Butterfly vertebra is an uncommon congenital disorder characterized by a symmetrical fusion defect resulting in a sagittal cleft vertebra ${ }^{2}$. Our case is vertebra fusion anomaly too, but not symmetrical.

Intervertebral disc was filled due to the lack of development of annulus fibrosis in cavity associated with the defect of embryological development of the vertebral corpus and trauma as a result of weakness in our case and it caused the patient to develop lumbar disc hernia. Therefore disc herniation could occur more easily in patients with vertebral body defect than in patients with normal vertebral body. Congenital vertebra corpus fusion anomalies are typically asymptomatic. However, these anomalies incidentally detected during routine radiographic investigations and post-traumatic radiological evaluations ${ }^{6}$. The specific radiological examinations usually include direct roentgenogram, CT and $\mathrm{MRI}^{15)}$. In our case, vertebral fusion defects were determined with lumbar radiograph performed due to back pain after trauma. Lumbar CT and MRI were taken in pursuit of radiograph. We thought that the defect occurred during the development in the embryological period of the vertebral body. However, that intervertebral disc was the weakest link as sufficient circular annulus fibrosis had not developed here. Thus annulus fibrosus resulted in herniation after the trauma depending on the weakness. There were no other osseous pathologies such as spina bifida occulta, facet abnormalities, and/or pedicle anomaly in our case.

Disc herniation in patients with congenital bone deformities associated with congenital developmental defects are considered related problems in the spinal canal. On the level of the patient's filum terminale, whether tethered cord syndrome should be investigated ${ }^{14)}$. There was not a congenital defect of development of the spinal canal in our case (Fig. 5). Presenting with similar symptoms, such as back and leg pain, especially adult clinical presentation patients with lumbar disc herniation group tethered cords can be confused with tethered cord. And therefore Lumbar MRI examinations should be well evaluated in the preoperative period ${ }^{4)}$.

\section{CONCLUSION}

These types of cases after trauma can be misevaluated and overlooked as congenital malformation without treatment. Especially, patients with congenital malformations and an unusual clinic should be examined carefully with advanced radiological imaging techniques.

\section{REFERENCES}

1. Battie MC, Videman T: Lumbar Disc Dejeneration Epidemiology and Genetic Influences. Spine 29(23):2679-2690, 2004

2. Cho HL, Kim JS, Paeng SS, Lee SH: Butterfly vertebra with lumbar intervertebral disc herniation. J Neurosurg Spine 15(5): 567-570, 2011

3. Dandy WE: Loose cartilage from intervertebral disk simulating tumor of the spinal cord. By Walter E. Dandy, 1929. Clin Orthop Relat Res 238:4-8, 1989

4. Gokay H, Barlas O, Hepgül HT: Tethered Cord in the adult 
mimicking the lumbar disc syndrome. Surg. Neurol 39:440-442, 1993

5. Güven O, Erol B, Bezer M: Konjenital skolyozun etiyolojisinde son gelişmeler. Türk Ortopedi ve Travmatoloji Dergisi 2:3-4, 2003

6. Harrop JS, Jeyamohan S, Sharan A: Acute cervical fracture or congenital spinal deformity? J Spinal Cord Med 31(1):83-87, 2008

7. Kulalı A: Microsurgical managament of the lumbar intervertebral disc disease. Marmara Medical J 4:7-11, 1991

8. Kutlay M, Cemil B, Topuz K, Demircan MN, Kucukodacı Z: Existence of Two Separate Facet Joints on the Same Side: Case of a Congenital Anomaly. Turk Neurosurg 21(2):239-241, 2011

9. Kyung-Soo S, Hwan-Mo L, Seong-Hwan M, Nam-Hyun K: Recurrent Lumbar Disc Herniation Results of Operative Management. Spine 6:672-676, 2001

10. Lowery LA, Sive: Strategies of vertebrate neurulation and a re-evaluation of teleost neural tube formation. Mech Dev. 121 (10):1189-1197, 2004

11. Mixter WJ, Barr JS: Rupture of the intervertebral disc with involvement of the spinal cord. New Engl J Med 211:210-215, 1934
12. Pye SR, Reid DM, Adams JE, Silman AJ, O'Neill TW: Influence of Weight, Body Mass Index and Lifestyle factors On Radiographic Features Of Lomber Disk Degeneration. Ann Rheum Dis 66:426-427, 2007

13. Sadler T. W: Embryology of Neural Tube Development American Journal of Medical Genetics Part C (Semin. Med. Genet.) 135C:2-8, 2005

14. Selçuki M, Umur Ş, Vatansever S, Sayın M, Temiz C, Selçuki D: Adult Type Tethered Cord Syndrome Presenting As Lumbar Disc Syndrome; Report Of Two Cases. Journal of Neurological Sciences (Turkish) 24(1);95-99, 2007

15. Sheehan J, Kaptain G, Sheehan J, Jane J Sr: Congenital absence of a cervical pedicle: Report of Two cases and review of the literature. Neurosurgery 47:1439-1442, 2000

16. Takashi K, Kasama F, Sato K, Kanabuchi T, Sato T: Congenital absence of lumbar articular process; report of four cases. Orthop Surg Traumatol 44:1321-1328, 2001

17. Tebbal MR, Ben Romdhane MH, Montagne JP, Ducou le Pointe H, Lipszyc H: What is it? Congenital absence of the left pedicle of C7 vertebra. J Radiol 79:1509-1512, 1998

18. Walker M, Anderson D: Molecular Basis of Intervertebral Disc Dejeneration. The Spine J 6:158-166, 2004 